\title{
Persuasion Act in the Proposal Movie
}

\author{
Gabriella Novianty Soedjarwo* \\ STIKS Tarakanita \\ E-mail: novianty.gabriella@gmail.com
}

\section{*(Corresponding Author)}

DOI: https://doi.org/10.1836/jopr.v2i1.50-67

Submission
Track:
Received:
17-03-2020
Final Revision:
03-04-2020
Available online:
10-04-2020
Corresponding
Author:
Gabriella Novianty
Soedjarwo
novianty.gabriella@gmail.
com

\begin{abstract}
The act of persuasion happens anywhere and anytime. When we need a help, we persuade other to do what we need. In order to have a successful persuasion, we apply certain strategy. This pragmatic paper wants to analyse the effective strategies in order to have an effective persuasive acts. Pragmatics is chosen as the method since the analysis is about the language used in certain context, in this case persuasion. This paper elaborates how certain speech acts can help the speaker to perform persuasion successfully. Besides, the researcher also analyses how the attempts of persuading violate certain maxims stated by Grice. The researcher took a movie entitled The Proposal (2009) as the data since it shows how the main characters apply certain speech acts and strategies in order to achieve effective persuasion. In this movie, Margaret and Andrew are trying to persuade each other in order to get different advantages through faking marriage. The researcher takes the dialogue of those two characters as the data. Then, the data was analysed using speech act theory, implicature, and language function theory on persuasion. The result of the study is the successful persuasion relies on using appropriate speech act, flouting the maxim of quantity, and applying good persuasive strategy.
\end{abstract}

Key words: Persuasion, Speech Act, Maxim, Strategy

\section{INTRODUCTION}

In communication, it happens many times that the attempt of those conversations is to make others do what the speaker wants. The forms of persuasive communication are advertisement and speech. Robin Lakoff as cited by Hardin (2010) defines persuasive discourse as the 
nonreciprocal "attempt or intention of one party to change the behaviour, feelings, intentions, or viewpoint of another by communicative means."

It is always interesting that we can figure out how certain act of speech can trigger someone to do something. In this movie, it can be obviously seen how those two characters use certain speech act to show how well they persuade each other. This persuasive attempt of communication agrees to Taillard (2000) who believes that persuading someone is performing an act using language. Since persuasive act is related to language thus in performing an act of persuasion is also related to certain speech act. The notion "speech act" is proposed at the first time by Austin in 1955. From this theory, it is important to take a look at how certain attempt to persuade is closely related to performing certain speech act.

This paper wants to find out what kind of language that enhances the successful persuasion. The focus of the study in this paper is how certain speech act and maxim applied in the persuasion can influence the success of the act of persuasion. Also the researcher analyses the strategy in having a successful persuasion.

Speech act theory is a part of pragmatics subject in linguistics. Pragmatics is a branch of linguistics which studies the language use, and in particular the study of linguistics communication, in relation to language structure and context of utterances. One of the topics discussed in pragmatics is speech acts. There are two theories of speech act: Austin's and Searle's theory on speech act. How those two theories are related will be discussed further in this session.

Speech acts are acts performed in uttering expressions. This theory is firstly introduced by John Austin in 1962 (Verschueren, 1999). Austin's speech act is defined as language is in fact a form of actins (in reaction to logical positivism, which did not accept meaning outside the realm of what could be tested for its truth or falsity. Austin concludes that an utterance contains both saying and doing act. There three types of speech act. The first type is locutionary. This speech act is defined as the act of saying something with particular sense and references. The second type is illocutionary. Illocutions are what is done in saying something. In other words, this speech act is defined as performing an act in saying something. The last type of speech act is perlocutionary which is defined as performing an act achieved by saying something. Perlocutionary effect refers to the effect of the utterance on the hearer; the hearer's reaction towards the utterance.

Searle proposes five categories of speech act namely assertive, directive, commissive, expressive, and declaration. The first category is assertive which is defined as expressing belief, 
making words fit to the world and committing the speakers to the truth of what is asserted. The next speech act is directives. Directives speech act has a definition expressing a wish, making the world fit the words and counting as an attempt to get the hearer to do something. The third speech act proposed by Searle is commissive. Commisive speech act is defined as expressing an intention, making the world fit the words and counting as a commitment for the speaker to engage in a future course of action. The next speech act is expressive which is defined as expressing a variety of psychological states, having no direction of fit between words and world, and simply counting as expressions of a psychological state. The last speech act proposed by Searle is declaration which is not expressing any psychological state, making both the words fit the world and the world fit the words, and the point of which is to bring about a change in (institutional) reality.

Theoretically, Searle's speech act is used to analyse illocutionary speech act proposed by Austin. Cutting (2002) explained that illocutionary act is the meaningful utterance. He explains more illocutionary force refers to the function of the utterances, the specific purpose that the speaker has in mind. Searle's speech act allows the researcher to know the aim of the illocutionary force. This statement agrees to Cutting's explanation that illocutionary act shows the purpose of the speaker in uttering the words which can be classified into inviting, advising, promising, ordering, excusing, and apologising.

Another major contribution in pragmatics besides the notion of speech act is Grice's theory of conversational implicature. Grice as cited by Verschueren (1999) suggested that our contribution in a conversation must be as required as the stage at which it occurs. Further, he explains our conversational contribution must be accepted in its purpose and direction of the talk exchange in which we are engaged. Related to this conversational contribution, Grice proposes four conversational maxims.

Speakers implicate, hearers infer. A successful communication relies on implicature. What it means by that statement is what a speaker implicates is often quite different from what her words imply or from what a hearer may be expected to take from them. However, it is what the speakers assume that the hearers will draw the appropriate interference from what is said 
that makes implicature a rational possibility. The principle of this notion is Cooperative Principle which states that make the speakers' conversation contributes such as it is required, at the stage at which it occurs, by the accepted purpose or direction of the talk exchange.

There are four general maxims to govern conversation rational interchange, as cited by Cruse (2004). The first maxim is maxim of quality. The term maxim of quality means try to make the contribution in a conversation is true. In order to achieve that, the speakers are not supposed to say what they believe to be false and they lack of evidence. The second maxim proposed by Grice is maxim of quantity. The term maxim of quality means make the contribution in the conversation as informative as is required. To achieve this maxim, the speakers need to speak in adequate meaning and information. The next conversational maxim is maxim of relation. Maxim of relation turns to be very simple. What it means in this maxim is having contribution in a conversation; the speakers need to be relevant. The speakers are expected to give the information which is related to the talk not other information which is out of the context. The last maxim is maxim of manner. In the maxim of manner, the speakers are expected to be perspicuous. What it means by being perspicuous is the speakers need to avoid obscurity of expression and ambiguity. The talk must be brief; avoid unnecessary prolixity and be order.

As in The Proposal movie the two main characters try to persuade each other in order to achieve their personal goals, it then becomes important to discuss the theory of persuasion in language. Rank (1976) as cited in Larson (2013, p.29) proposes a persuader's goal that are "implemented in the strategies he or she chooses, and these strategies are put in place using certain tactics." Rank's major strategies are for persuaders to intensify certain positive aspects of their product, cause, or candidate, or some negative aspect of the competition (Larson, 2013, p.29). This is relevant to what is seen in the movie that Margaret tries to convey the positive aspects when persuading Andrew to marry her by also revealing some negative consequences when Andrew does not follow her desire.

Another theory on persuasion is stated by Smith as cited by Haslett (2008), who proposes a contingency rules theory of compliance-gaining. She suggests that persuasive behaviours are selected in term of their anticipated consequences. She argues that "five self-evaluative and adaptive rules govern the selection of persuasive strategies in varied persuasive contexts: selfidentity rules link persuasive strategies to personal values; image maintenance-rules link persuasive strategies to impression-management concerns; environmental contingency rules relate persuasive strategies to concern about the physical well-being of the self and significant 
others; interpersonal relationship rules relate persuasive strategies to maintaining good relationships with others; and social normative rules link persuasive strategies to norms of appropriate behavior."

Combining the theory of speech act with the theory of persuasion as elaborated above, Taillard (2000) proved that there is a strong interlink between perlocutionary speech act with persuasion by citing Austin (1962), who first developed perlocutionary act using an example of the utterance "He persuaded me to shoot her". Besides, Austin also specifies the effects of perlocutionary acts as "certain consequential effects upon the feeling, thoughts or acts of the audience, or of the speaker, or of other persons" (Austin, 1962, p.101, as cited by Taillard, 2000, p. 147). Thus, "the production of cognitive, affective or behavioral effects on an audience by a speaker's utterance constitutes a perlocutionary act." (Taillard, 2000, p. 147).

There have been previous studies which talk about persuasion act. Hardin (2010) in his work states that in persuasion, the choice of linguistic forms and strategies indeed determine the success in the persuasion. Another previous study is done by Taufik in 2014. This study shows that although the act of persuasion belongs to directive speech act, but in fact this attempt is not merely a directive act. He analysed the persuasion act done by the candidates of mayor election in Pasuruan, East Java. This study reveals in persuasion act in which the purpose is to make other party does what the persuader desires, the persuader also delivers the commissive speech act; the persuader promises to do something in return to the hearer.

Another previous study being referred in this study is written by Altrikriti. He analyses the persuasive speech act done by Barack Obama in his speeches. He focuses on how the various kinds of speech act is used in order to gain more political power. Although persuasion act is a directive illocutionary act in which the speaker wants the hearer performs certain action, in this political speech the mostly used speech act is constative speech act. Constative speech ach is defined as the utterance aiming to affirm, answer, attribute, claim, and so on. Obama did not use directive so many time since Obama wants to show how he is able to answer the citizen's problem. He also uses a little commissive since he does to want to point out his promises only. Through the analysis, the conclusion is the effective strategy, in this case the choice of speech 
act, determines the success in the act of persuasion. In this political field constative illocutionary speech act is the best strategy to gain more political power.

\section{RESEARCH METHODOLOGY}

This study is the pragmatic study. This study belongs to pragmatic study since this study analyses the language used in the certain context, in this study the context is persuasion. It aims to reveal how to deliver an effective persuasive act. This study takes the data from the movie. The dialogues being analysed are those which contain the act of persuasion of the main characters.

Pragmatics, as it is explained by Verschueren (1999), focuses its study on resource-oriented explorations. In order to do that, the data for pragmatic study are usually in the form of texts, conversations, or discourse in general. Further he explains pragmatics as interdisciplinary analysis gives the researcher the insight on how language and human life in general are connected. Thus, pragmatic study regards all language used as the meaningful one to construct the meaning in the world.

In order to gather the data, the researcher watched the movie and transcript the dialogues which are regarded as the data analysis. The researcher also provides a summary of the movie in order to keep the discussion on the right tract. It is also important to keep in mind how the story is to determine which scenes represent the most suitable data.

As the main focus of this study is to analyse persuasion performed in speech acts, the researcher chose The Proposal movie as this movie contains a lot of persuasion attempts between the two main characters, Margaret Tate and Andrew Paxton. Each of the main character has a bargaining power, so they have their own ways in persuading each other. This study elaborates how those two characters finally succeed in performing an act of persuasion.

The data to analyse is taken by writing the transcript of the dialogue in the movie. However, not all the scenes are taken. Instead, the researcher only focuses on the dialogues which are directly related to the act of persuasion from the characters of Margaret Tate and Andrew Paxton. Next, the gathered data was analysed using speech act theory, implicature theory, and language functions theory.

\section{DISCUSSION \& RESULT}

There have been some studies which analysed how certain speech act used by interlocutor in his persuasive act can determines how effective his persuasion will be. This section discusses 
how the act of persuasion done by Margaret Tate and Andrew Paxton can be regarded as a successful act based on the theories employed in this study. To begin with, it is better to have a clear situation in which Margaret can come up with the idea of being married to an American man in order to get the green card to stay in American, since she is an immigrant. There have been many cases in which the immigrants, especially those who have gotten a good job or have been determined to stay, choose the "simple and easiest" way to get the permission to stay which is by marrying the local citizen. As it is widely known that marrying the local citizen can make the immigrant get the citizenship of that country especially for women. Thus, what Margaret is trying to do, she tries to persuade Andrew who is an American to marry her, is the ordinary decision to make to get the citizenship.

The movie tells a story about Margaret who is a successful Canadian editor in New York. She has a male assistant named Andrew Paxton. Margaret is a strict superior whose employees are afraid of her. Andrew Paxton, as her assistant, always tries hard to please her in order to be recognized as the talented editor. However, the conflict arises when an immigration officer comes to Margaret's office. Margaret is going to be deported since her visa application is rejected and her position will be replaced by Bob, an employee whom she has just fired. Not wanting to be replaced especially by Bob, she tries to persuade the officer by saying to the officer that she is getting married to an American man. Her idea of marriage rises when Andrew is entering the room while she is having the discussion. At first, Andrew rejects the idea of this fake marriage. However, Margaret tells him that when Bob is a chief, Andrew will be fired right away. Considering this to happen, Andrew agrees to have this fake marriage and he also asks for one condition; he asks Margaret to promote him to be an editor. Although Margaret is reluctant to promote Andrew to be an editor, she finally grants his demand since Margaret also needs Andrew's help.

The movie ends with the real marriage between Margaret and Andrew. However, as it has been mentioned earlier, this study focuses on how Margaret tries to persuade Andrew to have the fake marriage and, on the other hand, Andrew himself tries to persuade Margaret to promote him to be the editor in order to get his help. In this kind of situation, both of them neglect their 
position as the boss and the employee since they can use the situation to point the finger to each other. Andrew, regardless his lower position than Margaret, can make Margaret fulfil his demand, while Margaret points her finger at Andrew for being deported and will cause Andrew jobless.

After watching the movie and considering what dialogue is support the data, the researcher chose four dialogues to be analysed. The chosen dialogues being analysed in this study show the situation in which both parties, Margaret and Andrew, want to emphasise the consequences that they will suffer if they do not agree with the demand. Through their act of persuasion, it can be clearly seen that they want to be successful in getting the demand or not getting anything at all. Here are those four dialogues:

\section{Dialogue 1}

Margaret : Uh... Gentlemen, I understand, I understand... the predicament that we are in. and, um... and there's uh...well. I think there's something that you should know. Uh... we're, uh... we're getting married. We are getting married.

Andrew : Who is getting married?

Margaret : You and I. You and I are getting married. Yes.

Andrew : We are...

Margaret : getting married.

\section{Dialogue 2}

Margaret : Relax. It is for you too.

Andrew : Do explain.

Margaret : They were going to make Bob a chief.

Andrew : So naturally I would have to marry you.

Margaret : And what's the problem? Like you were saving yourselffor someone special?

Andrew : I like to think so. Besides, it's illegal.

Margaret : They're looking for terrorist, not for book publisher.

Andrew : Margaret.

Margaret : Yes?

Andrew : I'm not gonna marry you.

Margaret : Sure you are. Because if you don't marry me, your dreams of touching the lives of millions with the written words are dead. Bob is gonna fire you the second I'm gone. Guaranteed. That means you're out on the street alone, looking for a job.

\section{Dialogue 3}

Andrew : We couldn't tell anyone we work with because of my big promotion that I had coming up

Margaret : Your?

Andrew : that it would be deeply inappropriate if I were to be promoted to editor.

Margaret : Editor. Mmm...hmmm. 


\section{Dialogue 4:}

Margaret :OK. So, what's gonna happen is we will go up there. We will pretend like we're boyfriend and girlfriend, tell your parents we are engaged. Use the miles for the tickets. I guess I will pop for you to fly first class. But make sure you use the miles. If we don't get the miles, we're not doing it. (...)

Andrew :I'm sorry, were you not in that room?

Margaret : (...) Oh! The thing you said about being promoted? Genius! Genius. He completely fell for it.

Andrew : I was serious. I'm looking at a \$250,000 fine and five years in jail. That changes things.

Margaret : Promote you to editor? No, no way.

Andrew : Then I quit, and you're screwed. Bye-bye Margaret. (...leaving Margaret

Margaret : Andrew, Andrew! Fine, fine. I'll make you editor. Fine.

\section{Speech Act and Maxim Analysis}

Those four dialogues are going to be analysed using speech act theory, maxims theory, and language function in persuasion theory. By using those three theories, the researcher is going to find out what kind of utterance that is considered as a successful act of persuasion.

All meaningful utterances belong to illocutionary speech act. In this illocutionary act, the attempt of the act of the speaker can be categorised into five speech act proposed by Searle. Persuasion act, as it is defined as an attempt or intention of one party to change the behaviour, feelings, intentions, or viewpoint of another by communicative means by Lakoff, it is clear that persuasion belongs to directives speech act.

Before the analysis on how to deliver the effective persuasive act, the writer is going to explain the felicity condition in this movie. Austin, as cited by Cutting (2002), defines felicity condition as the context and roles of participants must be recognised by all parties; the action must be carried out completely, and the participants must have the right intention. Austin explains further, especially in directive and declarative, the rules applied in the felicity condition are the speaker must believe that it is possible to carry out the action: they are performing the act in the hearer's best interests; they are sincere about wanting to do it, and the words count as an act. 
In this movie, the persuasive act can be included into directive speech act as both parties, Margaret and Andrew, indirectly ask the other party to fulfil his and her demand. From the dialogues that have been chosen above, both of them have a situation to have an advantage from agreeing with the demand and a disadvantage from disagreeing with the demand. Margaret is interested in protecting her position as the chief editor, while Andrew is interested in being the editor. Facing this situation, both Margaret and Andrew believe that their act of persuasion will be successful.

Since, the act of persuasion done by Margaret and Andrew does not only contain the persuasion but also a promise to get the benefit from the deal, this act of persuasion in this movie can also belong to commissive speech act. As it has been explained earlier, commissive speech act is the act to promise something to the hearer. Both Margaret and Andrew promise to give something in return to each other when the other party agrees to fulfil the demand. As it can be seen from the movie Margaret promises Andrew to be the editor and Andrew promises Margaret to marry her.

From the Dialogue 1, Margaret tries to persuade the officer by saying that she is getting married to Andrew, who is an American. She expects her marriage to American man will change the officer mind to deport her. She is successful and the officer asks Andrew and her to come to the immigration office on the next day. Margaret's perlocutionary speech act can be seen from her attempt to make the immigration officer consider her visa application since she is going to marry to an American man. Her speech violates maxim of relation in which she suddenly tells about her marriage though their talk is not about marriage, they are talking about Margaret's visa application instead. Further, Margaret also violates maxim of quality because in fact she tells a lie about being married with an American man.

On the other hand, Andrew does not seem to know anything. He is confused why Margaret asks him to marry her. He demands an explanation from Margaret. They have an argument that can be seen in Dialogue 2. It is interesting how Margaret and Andrew perform different speech acts in persuading each other. In this Dialogue 2, Margaret uses perlocutionary speech act. She wants to infer that Andrew needs her to reach his dreams. So, if Margaret is deported and Bob replaces her, Bob will fire Andrew and his dreams are gone. On the other hand, Andrew uses illocutionary act in the form of expressive act. He directly expresses his feeling that he will not marry Margaret. It seems Margaret's speech is more effective in this persuasion because she indirectly threatens Andrew using exaggerated statements. Here, the maxim of quantity is violated. Apparently, Margaret could have said that she will lose the job if she is deported, 
which will be replaced by Bob. However, here she uses exaggeration such as "you're out on the street alone, looking for a job" and "your dreams of touching the lives of millions with the written words are dead".

However, in the next scene, Andrew changes his speech act. Despite his brilliance in using the right situation to persuade Margaret, his dialogue is also important to analyse. It is happened when both of them are in immigration office to apply their engagement. In Dialogue 3 we can see how Andrew answers the question from the immigration officer about the reason why they hide their engagement. He says that the reason they hide their engagement is because he is about to be promoted as an editor and it will be unethical if the other employees know that they are dating. What Andrew does in immigration office agrees to persuasive theory stated by Smith as cited in Haslett (2008) which says social normative rules link persuasive strategies to norms of appropriate behaviour. Andrew implies that hiding their engagement needs to be done in order to avoid gossip in the office.

Another interesting things happened in Dialogue 3 is it is obvious that besides applying the right speech act, the situation supports the success of Andrew's persuasion. Margaret, in this scene, is faced with the situation in which Margaret are supposed to agree to Andrew "demand" in front of the officer in order to get the permission to stay. His perlocutionary speech act aims to have a compensation of his agreement to marry Margaret by asking to get editor position. In Dialogue 3, Andrew violates maxim of quantity by exaggerating the situation in which they have to hide their marriage plan. He uses the expression deeply inappropriate which aims to points out exaggeratedly the situation to the immigration officer by using the adverb deeply to modify the inappropriateness.

From the speech act and maxim analysis and the classification of the attempt of the persuasive act, it can be seen there are some markers to show the act of persuasion. The marker being referred in this persuasive act here is the characteristic of persuasion act. It has been explained earlier that in order to have a successful persuasion, the persuader needs to apply the appropriate strategy. The most effective strategy in persuasion, it is proven in the movie as well, 
is intensifying the positive aspect of the persuader and highlighting the negative consequences if the opponent does not fulfil what the persuader desires.

\section{Persuasion Strategy}

Again in this Dialogue 4, Andrew's perlocutionary act can be seen through his utterance saying that he faces the fine and jail punishment. He actually wants to ask Margaret to promote him to be an editor. When Margaret still refuses his demand, he threatens Margaret that he will leave her and Margaret will be deported. The difference from those two reasons is the first one Andrew focuses on he himself as the "victim" which does not influence Margaret to accomplish Andrew's demand. While the second one, Andrew puts Margaret as the "victim" that Margaret will be deported which makes Margaret thinks that she really needs Andrew's help thus she will do anything to get the help.

After analysing those four dialogues, it can be concluded that the persuasions occur mostly in the form of intensifying the positive aspects of the persuader and highlighting the negative consequences if the opponent does not fulfil what the persuader wants. This is in accordance to Rank's model of persuasion that is a means of self-protection. In this movie's case, each character tries to protect their position. Margaret wants to protect her work visa in America; meanwhile Andrew wants to protect his career.

The act of persuasion can also be classified based on the purpose of the act itself. As Lakoff defines the persuasive as an act of changing other's behaviour and so on through language, the persuasive act done by Margaret Tate and Andrew Paxton can be classified based on those definition. From those four dialogues, the researcher classifies the persuasion act into two categories. The first category is the act of persuasion attempts to change the opponent's behaviour. It is happened in Dialogue 1 when Margaret wants to change the officer's behaviour toward her expired visa. The second category is the act of persuasion has an attempt to change the opponent's viewpoint. This category can be seen in Dialogue 2. In that dialogue, Margaret tries to change Andrew's viewpoint about their fake marriage. Margaret wants to make Andrew believe that their plan will not have such a bad consequences; Margaret illustrates that the immigration office will look for terrorist not a book publisher.

Through the analysis of those four dialogues, another thing needs to highlight is what those two characters, Margaret and Andrew, are doing during the process of persuasion. From the movie, Margaret is the first one who comes up with the idea of having a fake marriage in order to keep her position as an editor in chief. Andrew disagrees with her idea at first. However, Margaret can persuade him to agree with the idea by exaggerating the situation when Bob 
becomes his boss; Andrew will be jobless and cannot be an editor anymore. Considering those consequences, Andrew finally agrees to help Margaret.

However, when they both are about to apply for their marriage document to the immigration office, Andrew figures out that if they are caught to deceive the immigration office through fake marriage, Andrew will be fined and put in jail for helping the foreigner not to apply for visa. Seeing this situation, Andrew begins to think to make Margaret compensate for what he will do for her. So, he also tries to persuade Margaret to promote him to be an editor if Margaret still wants Andrew's help. Not having much time to look for another option, Margaret finally agrees with Andrew's demand.

From the explanation above, Referring Lakoff's definition on persuasion which is he defines as the nonreciprocal "attempt or intention of one party to change the behaviour, feelings, intentions, or viewpoint of another by communicative means." turns out to be inappropriate to define the persuasion act in the movie The Proposal. The analysis result of this study shows that act of persuasion is a reciprocal attempt of communication between Margareta and Andrew. The way the persuasion in this movie happens to be the reciprocal one in which the attempt of persuasion comes from two parties; Margaret who persuades Andrew to marry her and Andrew who persuades Margaret to promote him to be the editor. In this case, both Margaret and Andrew try to change each other behaviour and viewpoint.

From this movie, the most appropriate strategy in persuasion is as what is suggested by Rank (1976) as cited in Larson which mentions that a persuader's goal that are "implemented in the strategies he or she chooses, and these strategies are put in place using certain tactics." Rank's major strategies are for persuaders to intensify certain positive aspects of their product, cause, or candidate, or some negative aspect of the competition. Margaret intensifies her ability to make Andrew an editor since she is the editor in chief in the office. Andrew, on the other side, also intensifies his ability to make Margaret get her American citizenship by marrying him. Margaret also points out the bad effect that Andrew will suffer unless he agrees to Margaret's demand to have a fake marriage. Andrew highlights the bad consequence Margaret 
will suffer which is she will be deported and replaced by Bob if she does not want to promote him to be an editor.

\section{The Rhetoric of Persuasion}

Seeing those four dialogues, it can be concluded that the act of persuasion is delivered in certain way of utterances. In Dialogue 2 and Dialogue 3, in which the if clause is aimed to enhance the attempt of persuasion. Grammatically, the if clause, usually it is called conditional clause, shows the condition that will or would happened when the condition is met. However, when if clause is put in certain context, the aim is not just merely showing the possible or the impossible condition to happen, but it carries other function.

In this persuasion act, the if clause is aimed to threat the interlocutor if the interlocutor does not fulfil the demand asked in the act of persuasion. As it can be seen in Dialogue 2 in which Margaret uses if clause to threat Andrew to agree with the idea of having fake marriage, Margaret wants to threat Andrew by giving the condition that will happen if he does not agree to marry Margaret. Margaret says that Andrew will be jobless and he will not be able to fulfil his dream to touch the world through his work.

Andrew seems to use the same pattern of language, in this case if clause, to threat Margaret back. His attempt can be seen in Dialogue 3 when they are in the immigration office. Andrew says that it would be deeply inappropriate if I were to be promoted to editor. The if clause here shows that Andrew indirectly threats Margaret to promote him to be the editor if Margaret wants to continue having a fake marriage. Andrew intentionally says to the immigration officer that they have to keep their engagement as a secret since Andrew is about to be promoted as the editor, while in fact he has not been promoted yet.

From those two dialogues, it shows that the function of if clause does not just show the possible condition, but it serves a function as a threat addressed to the interlocutor. In this act of persuasion, the if clause is used to enhance the persuasion; if clause is aimed to make the persuasion becomes more urgent to consider. It proves that a certain utterance can serve many function depends on the context in which that expression is uttered.

Related to context of utterances, in the previous part of this paper it is called a felicity condition, there is one thing mentioned by Margaret in Dialogue 1 which is interesting to analyse. It is quite surprising why the affirmative sentence we're getting married spoken by Margaret, it can be considered as the first attempt of persuasion which causes to another persuasion to take place, gives such a big effect to the immigration officer to reconsider Margaret's deportation. It has been explained in the early part of the discussion in which 
marriage is the easiest and the fastest way for the foreigner to get a green card to live permanently in certain country. That is why when Margaret tells the immigration officer that she is going to marry an American man, the immigration officer wants to reconsider her deportation issue. If the utterance we're getting married is spoken in different condition, by the lover to their parents for example, of course the effect will be different from. The parents will be happy to hear that. However, in the movie it can be seen that the immigration officer looks startled since Margaret never talks about dating an American man.

Further, it is obviously that the sentence we're getting married is aimed to make the immigration officer feel certain that they are really will get married. Margaret even repeats that five times. She also interrupts, continue we can say, Andrew's sentence We are... because Margaret is afraid Andrew will say that they are not getting married, besides this moment she wants to make Andrew know that Margaret want they to get married.

\section{Meta-Language Aspect}

Analysing audio visual source is interesting since the researcher does not only analyse the utterance but also the meta language aspect of that utterances. The first meta language, in this part is suprasegmental features in phonetics, that can be analysed is from Dialogue 1, Margaret uses rising intonation in the end of the sentence when she says we are getting married in her fourth and fifth times. Based on Ladefoged (1993), it is hard to predict which word of group of words which has the highest pitch. In general, he adds, the highest pitch word in the intended information delivered to the hearer. Usually the affirmative sentence in English is ended with falling intonation, however, if the speaker uses the rising intonation in the end of the affirmative sentence, it means the speaker wants to emphasises that word. In Margaret's speech, she uses the highest pitch in the word married, it menas she wants to emphasis to the immigration officer that she is getting married to Andrew. Further, she also wants to convince the immigration officer that she is really getting married and to raise the exicetement.

Another meta language aspect in this dialogue is how Margaret in firstly uses many fillers such as $U h, u m$, and well since she has to thinks fast how to postpone his deportation. However, after she gets used to the idea of having fake marriage, she does not use any filler. In this case, 
filler indicates uncertainty of the speaker in uttering or delivering her idea. Further, she mentions We are getting married five times but in different construction also indicates that she only emphasis that fact of she will get married not to other things which in fact she does not have anything else to say. In her first time, she uses construction we're getting married and in the rest of her speaking, she uses the full construction We are getting married, even she uses gesture to point to Andrew and she herself as the one who will get married.

In Dialogue 4, Andrew also performs a meta language aspect in his utterance in which he purposely leave Margaret in the street when Margaret does not agree with his demand to promote him an editor. His action of purposely leaving and walking away from Margaret is proven to be effective in enhancing his persuasion to Margaret. Andrew can make Margaret is afraid of being left by him and being screwed by the condition. That is why, while Andrew is walking away from her, Margaret finally agrees to promote him to be an editor, even he can make Margaret kneel before him to propose him appropriately.

From the analysis, it is proven that meta language takes an important role to enhance the speech act, in this case the act of persuasion. It is likely to happen that the effect of persuasion will not be that great unless the speech act is supported by appropriate meta language, in this case gesture and intonation.

\section{CONCLUSION}

Speech acts has a strong influence on the way people persuade. In persuasion, the persuader tries to convince the opponents to do the intended actions. In order to have successful persuasion, one needs to have the appropriate strategies. One of the strategies that occur in the movie is by using indirect speech acts. In The Proposal movie, perlocutionary speech act is applied while applying other strategies as well, such as violating maxim of quality, make the persuasion effective. In general, it can be concluded that the persuasive act in this movie is aimed to change behaviour and viewpoint. Margaret wants to change the immigration officer's behaviour, so she won't be deported. She also wants to change Andrew's viewpoint about having a fake marriage to be something that is beneficial for him as well. Andrew has an intention to change Margaret's behaviour, from seeing Andrew as an incapable editor, while in fact he is a capable to be one, to seeing Andrew as a potential person to be a great editor.

The act of persuasion by applying the appropriate strategy is proven to be effective regardless the different social class between the persuader and the opponent. The persuader, it can be seen from the character of Margaret, does not need or even do not directly ask the opponent to do the desired action, but by asking it indirectly for example by threatening and 
pointing out the persuader's quality that is needed by the opponent, which violates maxim of quantity, is the effective way to be successful in persuasion. In other words, it can be said that the more vocal the persuader is, the less effective his persuasion is.

This study also reveals that, in fact, the definition of persuasion from Lakoff is inappropriate since the act persuasion can happen in two ways between the persuader and the hearer. The movie The Proposal shows this kind of persuasion act as well. The attempt of persuasion does not only come from one party, Margaret Tate who comes up with the idea of having fake marriage, but also comes from the hearer; Andrew Paxton who wants Margaret to repay what he will do for her. In this situation, the persuasion is a reciprocal communication, not the nonreciprocal one.

\section{REFERENCES}

Altikriti, S. (2016). Persuasive Speech Acts in Barack Obaman's Inaugural Speeches (2009, 2013) and The Last State of the Union Address (2016). International Journal of Linguistics. 8: 47-66.

Cruse, A. (2004). Meaning in Language An Introduction to Semantics and Pragmatics Second Edition. Oxford: Oxford University Press.

Cutting, J. (2002). Pragmatics and Discourse A resource book for students. New York: Routledge.

Hardin, K. J. (2010). Trying to Persuade: Speech Acts in the Persuasive Discourse of Intermediate Spanish Learners In Kenneth A. McElhanon and Ger Reesink, A Mosaic of Languages and Cultures: Studies Celebrating the career of Karl J. Franklin. 155-179.

Haslett, B. B. (2008). Communication: Strategic Action in Context. New York: Routledge.

Horn, L.R \& Ward, G. (2007). The Handbook of Pragmatics. Oxford: Blackwell Publishing, Ltd.

Ladefoged, P. (1993). A Course in Phonetics. Los Angeles: Harcourt Brace Jovanovich College Publishers. 
Larson, C. U. (2013). Persuasion: Reception and Responsibility, Thirteenth Edition. MA: Wadsworth.

Taillard, M-O. (2000). Persuasive Communication: The Case of Marketing. UCL Working Paper in Linguistics (Vol 12). Retrieved from http://citeseerx.ist.psu.edu/messages/downloadsexceeded.html

Taufik, K. S. (2014). The Persuasive Utterances in a Political Discourse (The Case Study of the Regent Election Campaign of Pasuruan, East Java). International Journal of Linguistics. 6: 192-208.

Verschueren, J. (1999). Understanding Pragmatics. New York: Arnold Publishers. 